\title{
OPTIMIZATION OF MEDIA AND CONDITIONS FOR CALLUS INDUCTION FROM ANTHERS OF SESAME CULTIVAR MI 3
}

\author{
K.K.D.S. RANAWEERA AND R. PATHIRANA \\ Department of Agronomy, Faculty of Agriculture, University of Ruhuna, Kamburupitiya.
}

(Date of receipt $\quad: \quad 21$ July 1992)
(Date of acceptance $:$ 02 November 1992)

\begin{abstract}
Murashige and Skoog (MS) medium supplemented with different concentrations of 2,4-dichlorophenoxyacetic acid (2,4-D), 3-indoleacetic acid (LAA) and 6-benzylaminepurine (BAP) were used to induce callus from anthers of sesame (Sesamum indicum L.) cultivar MI 3 as an initial step towards developing a protocol for the haploid production for use in the breeding. Anthers from flower buds $36-48 \mathrm{~h}$ before anthesis incubated at $8^{\circ} \mathrm{C}$ for $24 \mathrm{~h}$ in the dark gave the best results. Out of the media studied, $\mathrm{MS}_{5}$ medium containing $10 \mathrm{mg} / \mathrm{l}$ of $2,4-\mathrm{D}$ and $2 \mathrm{mg} / \mathrm{l}$ each of IAA and BAP gave the highest rate of callus induction (46\%) within 2.3 weeks of plating. For sub-culturing, both $\mathrm{MS}_{5}$ and $\mathrm{MS}_{4}(5 \mathrm{mg} / \mathrm{l}$ of 3 -indoleacetic acid and $3 \mathrm{mg} / \mathrm{l}$ of benzylaminepurine) media gave satisfactory results, with $\mathrm{MS}_{5}$ recording $78 \%$ and $\mathrm{MS}_{4} 60 \%$ callusing. Calli produced in these two media were soft and yellow-coloured. In $\mathrm{MS}_{5}$ medium they exceeded $2 \mathrm{~mm}$ in diameter. These calli have been transferred to regeneration media for optimising conditions for haploid production.
\end{abstract}

Key words: Anther culture, Sesame, Gingelly, Sesamum indicum L., haploids, callus induction.

\section{INTRODUCTION}

Sesame (Sesamum indicum L.) is an important oilseed crop with a large number of land races and cultivars adapted to a wide range of climatic conditions. ${ }^{1-3}$ It is economically the most important annual oilseed crop in Sri Lanka. For all practical purposes it is treated as a self-pollinated species although varying degrees of cross-pollination have been reported. ${ }^{1,3-7}$ Doubled haploids (DH) offer an efficient and rapid method of improving self-pollinated crop species if suitable protocols for haploid production, diploidization and regeneration are available. ${ }^{8-10}$ The DH method has already been used to improve a range of agronomically important characters in several crops such as rice, ${ }^{11,12}$ barley, ${ }^{13,14}$ wheat $^{15,16}$ and Brassica $s p .^{17-19}$ Modified Murashige and Skoog (MS) medium has been used successfully to induce callus from sesame anthers of cultivars of exotic origin. ${ }^{20,21}$ However, under the same culture conditions significant differences among genotypes have been observed. ${ }^{10,15,22-25}$ Therefore, efficient haploid production from locally adapted high yielding cultivars is a prerequisite for using this methodology in crop improvement. 
Optimal stage of the explant and culture conditions for efficient callus induction and sub-culture of anthers of MI 3 variety, the only recommended white seeded sesame cultivar in Sri Lanka are reported here.

\section{MATERIALS AND METHODS}

The cultivar MI 3 used in this study is the only recommended variety in Sri Lanka having white seeds. It has a non-branching stem, opposite leaf arrangement with three bicarpellate capsules per leaf axil. Flower buds in three stages of development were studied for callus formation from anthers. These were the small ( $48-60 \mathrm{~h}$ before anthesis), medium (36-48 $\mathrm{h}$ before anthesis) and large buds (24-36 $\mathrm{h}$ before anthesis). Flower buds were surface-sterilized with $70 \%$ ethanol for 5 s and then rinsed in autoclaved distilled water prior to extracting anthers under aseptic conditions for plating. Callus formation from anthers treated at $8^{\circ} \mathrm{C}$ for $24 \mathrm{~h}$ and $48 \mathrm{~h}$ was compared with untreated ones which were directly plated without cold treatment.

Murashige and Skoog (MS) medium ${ }^{2 \epsilon}$ has been the most effective one for callus induction in sesame. ${ }^{20,21}$ Five MS based media with different levels of hormones were used in the present studies (Table 1). The $\mathrm{pH}$ value of media was adjusted to $5.8 \pm$ 0.1 with $0.1 \mathrm{~N} \mathrm{NaOH}$ or $0.1 \mathrm{~N} \mathrm{HCl}$. The effect of the presence or absence of light on the callus induction of plated anthers was also investigated. The effects of the total absence of light and a photoperiod of $12 \mathrm{~h}$ per day from fluorescent tubes at 2000 lux were compared. The plated anthers and subcultured calli were maintained at a temperature of $25 \pm 1^{0} \mathrm{C}$.

Table 1: Hormone composition of MS media used in the experiments (mg/l)

\begin{tabular}{lccccc}
\hline Hormones & $\mathrm{MS}_{1}$ & $\mathrm{MS}_{2}$ & $\begin{array}{c}\text { Medium } \\
\mathrm{MS}_{3}\end{array}$ & $\mathrm{MS}_{4}$ & $\mathrm{MS}_{5}$ \\
\hline 2,4-D & 10 & 15 & 20 & - & 10 \\
IAA & - & - & - & 5 & 2 \\
BAP & 1 & 1 & - & 3 & 2 \\
\hline
\end{tabular}

\section{RESULTS}

Flowers at the 'medium stage' having a length of 5-7 $\mathrm{mm}$ and $36-48 \mathrm{~h}$ prior to anthesis gave the highest rate of callus induction. The flower buds of this stage were therefore used in subsequent experiments. Out of a total of 1077 anthers which produced calli, 947 (88\%) remained green until longitudinal splitting. Of the 6123 anthers which turned brown within a few days of plating, only 613 (10\%) produced calli. Thus, $90 \%$ of the anthers which turned brown failed to produce callus. 
In the preliminary studies with different temperatures of pretreatment of anthers, the highest number of calli (199 out of 1200 plated anthers) were produced when the anthers were incubated at $8^{0} \mathrm{C}$ for $24 \mathrm{~h}$. Incubation at $8^{\circ} \mathrm{C}$ for $48 \mathrm{~h}$ resulted in the callus production from 154 out of 1200 anthers. Direct plating without a cold treatment resulted in only 71 anthers producing callus out of 1200 anthers. This experiment was conducted only with $\mathrm{MS}_{1}$ medium and further experiments were carried out using anthers from flower buds of 'medium stage' of development incubated at $8^{0} \mathrm{C}$ for $24 \mathrm{~h}$.

Among the media used $\mathrm{MS}_{1}, \mathrm{MS}_{2}, \mathrm{MS}_{4}$ and $\mathrm{MS}_{5}$ were capable of inducing callus from anthers of MI 3 variety (Table 2). All four media had one or two of auxins 2-4 dichlorophenoxyacetic acid (2,4-D) and 3-indoleacetic acid (IAA) and a cytokinin 6-benzylaminepurine (BAP), whereas $\mathrm{MS}_{3}$ medium which failed to induce callus had only 2,4-D, but in greater concentration than the rest (Table 1 ). Callus induction in $\mathrm{MS}_{5}$ medium occured within 2 weeks of plating compared to 3-4 weeks in other media. A relatively greater proportion of anthers plated on this medium produced callus (Table 2). The first response of most anthers that gave callus was the longitudinal splitting within a week after plating. Continuous darkness was better than a photoperiod of $12 \mathrm{~h}$ per day on $\mathrm{MS}_{2}$ and $\mathrm{MS}_{4}$ media for callus formation (Table 2). Experiments on callus induction with $\mathrm{MS}_{5}$ medium were therefore continued in the absence of light.

Table 2: Callus induction capacity of media from anthers of medium size $(5-7 \mathrm{~mm})$ flower buds of sesame

\begin{tabular}{cccc}
\hline Medium & Treatment & $\begin{array}{c}\text { Number of anthers } \\
\text { producing callus }\end{array}$ & $\begin{array}{c}\text { Percentage of } \\
\text { callus induction }\end{array}$ \\
\hline $\mathrm{MS}_{1}$ & Light & 199 & 17 \\
\hline $\mathrm{MS}_{2}$ & Light & 80 & 7 \\
& Dark & 111 & 9 \\
\hline $\mathrm{MS}_{3}{ }^{\prime}$ & Light & 0 & 0 \\
& Dark & 0 & 0 \\
\hline $\mathrm{MS}_{4}$ & Light & 60 & 7 \\
\hline $\mathrm{MS}_{5}$ & Dark & 80 & 46 \\
\hline
\end{tabular}

1200 anthers were plated for each treatment.

Calli derived from anthers were cultured in four different MS based media viz. $\mathrm{MS}_{2}, \mathrm{MS}_{3}, \mathrm{MS}_{4}$ and $\mathrm{MS}_{5}$ (Table 1). Response to reculture was found to be different 
in the four media (Table 3). The $\mathrm{MS}_{5}$ medium containing three hormones proved to be the best among those tested. Calli formed on the $\mathrm{MS}_{2}$ medium were relatively hard and brownish. They were globule like structures less than $1 \mathrm{~mm}$ in diameter. When these calli were transferred again to $\mathrm{MS}_{4}$ or $\mathrm{MS}_{5}$ media, they formed callus tissues similar to those usually grown in the latter two media, being yellowish and soft. However, calli subcultured from $\mathrm{MS}_{4}$ and $\mathrm{MS}_{5}$ media were more capable of callusing than those from $\mathrm{MS}_{2}$.

Table 3: Callus formation on different media after reculture

\begin{tabular}{|c|c|c|c|}
\hline \multirow{2}{*}{ Medium } & \multicolumn{2}{|c|}{ Response of plated callus } & \multirow{2}{*}{ Characteristics } \\
\hline & $\begin{array}{l}\text { Percentage of } \\
\text { callus formation }\end{array}$ & $\begin{array}{l}\text { Size of callus } \\
\text { formed }\end{array}$ & \\
\hline $\mathrm{MS}_{2}$ & $45.5 \pm 0.7$ & + & $\begin{array}{l}\text { brown, globular } \\
\text { and hard calli }\end{array}$ \\
\hline $\mathrm{MS}_{3}$ & 0 & -- & -- \\
\hline $\mathrm{MS}_{4}$ & $60.0 \pm 1.7$ & + & yellowish soft calli \\
\hline $\mathrm{MS}_{5}$ & $77.8 \pm 1.8$ & +++ & yellowish soft calli \\
\hline
\end{tabular}

\section{DISCUSSION}

Shortening of the breeding cycle using DH technology can be achieved only if different stages take short periods. $8,13,17,18$ All the media which were capable of producing callus were efficient in this context as they induced callus within 2-4 weeks. Nevertheless, $\mathrm{MS}_{5}$ was the most successful medium as callus induction in it took place within 2 weeks compared to 3-4. weeks in other media. Moreover, a greater proportion of plated anthers produced callus in this medium.

The position of anthers on the medium at the time of plating also seems to have an influence on the callus induction. This aspect needs further investigations and should contribute to increasing the callus yield.

According to the only published results of anther culture in sesame, the Korean cultivars used have given $55.1 \%$ callus induction when $25 \mathrm{mg} / 1$ of $2,4-\mathrm{D}$ and $1 \mathrm{mg} / \mathrm{l}$ of BAP were included in the MS medium. ${ }^{20}$ Our experiments indicate that 
concentration of $15 \mathrm{mg} / \mathrm{l}$ of $2,4-\mathrm{D}$ with $1 \mathrm{mg} / \mathrm{l}$ of $\mathrm{BAP}\left(\mathrm{MS}_{2}\right)$ does not give a satisfactory rate of callus induction. The $\mathrm{MS}_{1}$ medium containing $10 \mathrm{mg} / \mathrm{l}$ of 2,4-D with $1 \mathrm{mg} / \mathrm{l}$ of BAP recorded a higher rate of callus induction than $\mathrm{MS}_{2}$ medium with $15 \mathrm{mg} / 1$ 2,4-D. These results are consistent with the findings that the different genotypes require different media for callus induction from anthers of the same species. $10,15,22-25$

Anthers from flower buds $36-48 \mathrm{~h}$ before anthesis, incubated for $24 \mathrm{~h}$ at $8^{0} \mathrm{C}$ when plated on $\mathrm{MS}_{5}$ medium and kept in total darkness produced the highest rate of callus induction in the present experiment. With the objective of producing haploid plants, calli obtained from anthers of MI 3 variety have been transferred to regeneration media with different ratios of hormones. Besides, different media with natural sources are being tested for anther culture of several promising sesame genotypes including MI 3.

\section{Acknowledgements}

This research was supported under grant No. 936-5542, Program in Science and Technology Corporation of the U.S. Agency for International Development funded through the Natural Resources, Energy and Science Authority and grant No. RC 5442 from the International Atomic Energy Agency, Vienna. The authors thank Miss Champika Hewage and Miss Seetha Gunarathna Menike for technical assistance.

\section{References}

1. Ashri A. (1989). In : Oil Crops of the World (Eds. G. Robbelen, R.K. Downey \& A. Ashri) pp. 375-387. McGraw Hill Publishing Company, New York.

2. Brar G.S. \& Ahuja K.L. (1979). In : Annual Review of Plant Science (Ed. C.P. Malik) pp. 247-213. Kalyani Publishers, New Delhi.

3. Weiss E.A. (1983). Oilseed Crops. Longman, London.

4. Joshi A.B. (1961). Sesamum. Indian Central Oilseeds Committee. Hyderabad, India.

5. Khidir M.O. (1972). Natural cross-fertilization in sesame under Sudan conditions. Experimental Agriculture $8: 55-59$.

6. Langham D.G. (1944). Natural and controlled pollination in sesame. Journal of Heredity $35: 255-256$.

7. Van Rheenen H.A. (1980). Aspects of natural cross-fertilization in sesame (Sesamum indicum L.). Tropical Agriculture (Trinidad) 57 : 53-59.. 
8. Morrison R.A. \& Evans D.A. (1988). Haploid plants from tissue culture : New plant varieties in a shortened time frame. Biotechnology $6: 684-688$.

9. Snape J.W. (1989). In : Genetic manipulation in crops : Review of advances in Plant Biotechnology, 1985-88. pp. 19-30. International Maize and Wheat Improvement Centre, Mexico City.

10. Szarejko I., Maluszynski M., Polok K. \& Kilian A. (1991). In : Plant Mutation Breeding for Crop Improvement. Vol. 2. pp. 355-378. International Atomic Energy Agency, Vienna.

11. Zapata F. J., Torrizo I.B., Aldemita R.R.\& Novero A.U. (1985). In : Rice Genetics. pp. 773-780. International Rice Research Institute, Los Banos, Philippines.

12. Zapata F. J. \& Aldemita R.R.( 1989). In : Current options for cereal improvement (Ed. M. Maluszynski) pp. 193-202. Kluwer Academic Publishers, Dordrecht.

13. Foroughi - Wehr B. \& Friedt W. (1984). Rapid production of recombinant barley yellow mosaic virus resistant Hordeum vulgare lines by anther culture. Theoretical and Applied Genetics $67: 377-382$.

14. Ye J.M., Kao K.N., Harvey B.L. \& Rossnagel B.G. (1987). Screening of salt-tolerant barley genotypes via $F_{1}$ anther culture in salt stressed media. Theoretical and Applied Genetics $74: 426-429$.

15. Andersen S.B., Due I.K., \& Olesen A. (1988). Results with anther culture in some important Scandinavian varieties of wheat. Acta Agricultura Scandinavia 38 : 289-292.

16. Baenziger P.S., Peterson C.J., Morris M.R. \& Mattern P.J. (1989). In : Current options for cereal improvement. (Ed. M. Maluszynski) pp. 1 - 9. Kluwer Academic Publishers, Dordrecht.

17. Beversdorf W.D. \& Kott L.S. (1987). An in vitro mutagenesis / selection system for Brassica napus. Iowa State Joumal of Research 61 : 435-443.

18. Hoffman F., Thomas E. \& Wenzel G. (1982). Anther culture as a breeding tool in rape. II. Progeny analyses of androgenetic lines and induced mutants from haploid cultures. Theoretical and Applied Genetics 61:225- 232.

19. MacDonald M.V., Ahmed I., Menten J.O.M., Howe M. \& Ingram D.S. (1989). Haploid culture and in vitro mutagenesis to induce resistance to disease in Brassica napus. Aspects of Applied Biology 23 : 471-475. 
20. Anonymous (1986). Sesame breeding and agronomy in Korea. Crop Experiment Station, Rural Development Administration, S. Korea. p. 61 .

21. Simmonds J. \& Keller W. (1987). In : Oil crops : Niger and Rapeseed/Mustard Proceeding of the third oil crops network workshop, Addis Ababa, Ethiopia, 6-10 October, 1986. pp. 220-224. International Development Research Center (IDRC-MR 155e), Ottawa.

22. Foroughi - Wehr B. \& Zeller F.J. (1990). In vitro microspore reaction of different German wheat cultivars. Theoretical and Applied Genetics 79 : 77-80.

23. Powell W. (1988). Diallel analysis of barley anther culture response. Genome 30 : 152 - 157.

24. Quimio C.A. \& Zapata F.J.(1990). Diallel analysis of callus induction and green-plant regeneration in rice anther culture. Crop Science $30: 188-192$.

25. Tuvesson I.K.D., Petersen S. \& Anderson S.B. (1989). Nuclear genes affecting albinism in wheat (Triticum aestivum L.) anther culture. Theoretical and Applied Genetics $78: 879-883$.

26. Murashige T. \& Skoog F. (1962). A revised medium for rapid growth and bioasseys with tobacco tissue callus, Physiologia Plantanum 15 : 473-497. 